Article

\title{
Econometric Estimation of the Factors That Influence Startup Success
}

\author{
Carlos Díaz-Santamaría *(D) and Jacques Bulchand-Gidumal \\ Institute of Tourism and Sustainable Economic Development (TIDES), Campus de Tafira, University of Las \\ Palmas de Gran Canaria, 35017 Las Palmas, Spain; jacques.bulchand@ulpgc.es \\ * Correspondence: carlos.diaz@ulpgc.es
}

\begin{abstract}
Technology startups are important regional economic engines that are recognized as drivers of sustainable economic growth. Understanding the factors that influence their success is of interest both to the scientific community and to practitioners. However, there is currently no consensus in the literature on how to define the success of a technology startup. Startup success has multiple dimensions and different theoretical approaches and empirical contexts. Therefore, in the present work, our aim is to identify ways of measuring the success of a technology startup. Using a review of the literature and interviews with entrepreneurs and venture capital investors, we identified two common success indicators: achieving significant revenue and obtaining financing. We then analyzed the factors that have the greatest impact on startup success using 340 startups. We used a multivariate model based on independent econometric estimates for each of the two ways of defining the success of a technology startup. The main conclusion is that there are four factors that have a significant influence on the two ways of measuring success: the location of the startup, the promoting partners' dedication, the age of the company, and the existence of nonpromoting partners.
\end{abstract}

check for

updates

Citation: Díaz-Santamaría, C.; Bulchand-Gidumal, J. Econometric Estimation of the Factors That Influence Startup Success. Sustainability 2021, 13, 2242. https:// doi.org/10.3390/su13042242

Academic Editor: João Leitão

Received: 19 December 2020

Accepted: 17 February 2021

Published: 19 February 2021

Publisher's Note: MDPI stays neutral with regard to jurisdictional claims in published maps and institutional affiliations.

Copyright: (c) 2021 by the authors. Licensee MDPI, Basel, Switzerland. This article is an open access article distributed under the terms and conditions of the Creative Commons Attribution (CC BY) license (https:/ / creativecommons.org/licenses/by/ $4.0 /)$.
Keywords: success; entrepreneurship; startup; multivariate analysis; Spain

\section{Introduction}

Technology startups are important engines for regional job creation [1,2] and are recognized for their key role in innovation and economic growth $[3,4]$. These organizations also help traditional sectors develop, adding value to innovation and knowledge [5], and are recognized as engines of sustainable economic growth.

Startups show high potential in the medium and long term through their active contributions to a country's sustainable economic development [6]. Several works have shown that promoting startups is a key action point for encouraging economic growth [7]. Innovative products and services are the inspiration for many startups [8]. As the OECD [9] has indicated, startups promote structural change in the economy, contributing to the creation and introduction of new knowledge-intensive products and services. With the evolution of new technologies, new business models of startups have been evolving and adapting to include new processes and social changes, as well as new demands from consumers such as sustainable values [10].

While traditional companies operate within traditional models, startups develop innovative models and act under conditions of extreme uncertainty [11]. These conditions, together with the fact that these types of companies are sometimes far from the main economic and political nodes, may make it more difficult for them to access private or public funds, which damages their growth possibilities [12].

Therefore, identifying why technology startups succeed is of value for the different agents that are part of the startup ecosystem [13], such as the startups themselves, investors, and public administrations.

For startups, information on the factors that influence their possible success would allow them to identify keys for better functioning. Investors in startups, on their part, 
would have better information on the type of companies in which they could invest and what to look for in the startups they are investing in.

Last, this information would be particularly useful for public administrations, especially considering their commitment to this type of company. On the one hand, public administrations invest public funds to involve startups in challenges to implement new smart solutions for cities [14]. On the other hand, public administrations also make both economic resources (e.g., financing, training, consulting, mentoring) and physical and infrastructure resources (e.g., incubators, coworking spaces, accelerators) available to startups [15]. It is noteworthy that acceleration programs have been, and continue to be, increasingly important in promoting these types of startups [16]. A suitable choice between different acceleration programs may imply a significant economic difference to the performance of the startup [17] and that incubators can provide networks that induce opportunities for startups and the appearance of unexpected startups [18].

If we focus on the main characteristics of technology startups, we can find some common denominators [5]: the technological base, the independent character (i.e., ownership predominantly by the founder or founders), the novelty (i.e., the technology used and the product or final service provided), the size of the company (usually medium or small), and the search for a scalable and replicable business model. Additionally, these technology startups seek to acquire financial resources to demonstrate their ability to move from the conceptualization phase to the commercialization phase [19].

Regarding the concept of success for a technology startup, the first thing to consider is that startup success has multiple dimensions and different theoretical approaches and empirical contexts. The literature mentions some key factors for obtaining success, but without identifying a common denominator or what is understood as success for these startups. Success means different things to researchers. Additionally, there are no integrated models that consider all of the factors that might make a technology startup successful. In the cases where such models exist, they tend to be reviews of the literature without empirical verification [20].

Therefore, the main objective of the present study is twofold: to determine a series of commonly agreed measures of startup success and to analyze which factors have the greatest impact on that success. To this end, in the next section, we conduct a review of the literature to define an integrated model of all the possible factors that may influence the success of technology startups. We also analyze how success has been defined in the current literature. After that, we explain the details of the methodology we followed to carry out field work. First, we interviewed 50 entrepreneurs and 15 venture capital investors about how they measure the success of a startup. Then, we used the responses from 340 technology startups in Spain to explain what factors affect the two ways of measuring the success of startups. After discussing these results, we present the main conclusions that can be drawn regarding economic policy for governments, founders, and the companies themselves.

\section{Literature Review}

The academic literature analyzing the concept of "success" in startups is wide and varied. A better understanding of the factors that contribute to startup success represents a critical aspect of entrepreneurship studies [13]. In our case, we will review the literature from two perspectives: the factors that lead to the success of startups (in whichever way success is defined) and the methods that the literature proposes for measuring the success of startups. To broadly summarize the literature, three aspects can be observed that predict the success or failure of new companies. The first, being the most classic, focuses on the figure of the entrepreneur and analyzing the profile of the entrepreneur.

The second aspect focuses on the strategy and characteristics of the company, by specifically analyzing the strategy that the entrepreneur chooses for the company and what type of company it is. This aspect focuses less on the traits of the entrepreneur (what the entrepreneur is like) and more on their behaviors (how they do things), so their attitudes, 
capacities, or abilities as well as their experience are carefully studied since they directly affect the implementation progress of the company's strategy.

The third and last aspect is related to the influence that the environment may have on the development of the company, formed by main factors such as the availability of capital, qualified human resources, and infrastructure.

In relation to the figure and profile of the entrepreneur [21-25], the factors mentioned in this area are presented in Table 1.

Table 1. Key factors of the entrepreneur profile influencing the success of startups.

\begin{tabular}{cc}
\hline Factors & References \\
\hline Previous working experience & {$[26-37]$} \\
\hline $\begin{array}{c}\text { Skills, abilities, and previous managerial and } \\
\text { commercial experience }\end{array}$ & {$[35,38-49]$} \\
\hline Previous experience as a founder of other startups & {$[50-53]$} \\
\hline Training & {$[35,54-59]$} \\
\hline
\end{tabular}

The second focuses on analyzing the strategy that the entrepreneur chooses for the company and what type of company it is. This factor focuses on their behavior and how they manage the company [60-63]. This second group of factors is presented in Table 2.

Table 2. Key factors of the strategy and characteristics of the company with an influence on the success of startups.

\begin{tabular}{cc}
\hline Factors & References \\
\hline Startup age & {$[64]$} \\
\hline Size of the startup & {$[65-70]$} \\
\hline Definition and development of a business strategy for the startup & {$[49,60,62,63]$} \\
\hline $\begin{array}{c}\text { Development of a financial strategy: initial investment and } \\
\text { opening to equity capital }\end{array}$ & {$[35,71,72]$} \\
\hline Development of a technological innovation strategy & {$[73,74]$} \\
\hline Development of a market positioning strategy & {$[34,47,49]$} \\
\hline Good financial health & {$[69,75]$} \\
\hline
\end{tabular}

The third factor is related to the influence the environment may have on the development of the company, as outlined by Stearns et al. [76] and Tsai et al. [77], among others. These factors are found in Table 3.

Table 3. Key factors of the environment influencing the success of startups.

\begin{tabular}{cc}
\hline \multicolumn{1}{c}{ Factors } & References \\
\hline $\begin{array}{c}\text { Market conditions (growth) and the } \\
\text { environment in general }\end{array}$ & {$[49,76,77]$} \\
\hline $\begin{array}{c}\text { Indirect experiences in entrepreneurship } \\
\text { (parents, friends, family) }\end{array}$ & {$[27,78]$} \\
\hline Financial constraints (e.g., sources of financing) & {$[68,70,79-82]$} \\
\hline Location, effects of cities and infrastructure & {$[29,35,60]$} \\
\hline $\begin{array}{c}\text { Support received from public administrations } \\
\text { (e.g., through business incubators) }\end{array}$ & {$[83]$} \\
\hline
\end{tabular}


This list of factors suggests that there are many factors that influence the possible success of a startup.

Based on the methods for measuring the success of startups proposed in the literature, there is no unique way to define the success of a startup [20]. Success was defined as "a combination of economic and subjective measures" [84] (p. 474). McCormack [85] defined entrepreneurial success as "what you do to help change the community" (p. 48). Restrepo et al. [86] used the concept of durability instead of success and suggested that when referring to success, survival is one of the objectives of any company, along with profitability and growth. In the same vein, it was argued that success depends on what the entrepreneur wants to do with their life [5]. If the entrepreneur does not enjoy what they are going to do, they will be closer to failure than success.

On the other hand, many entrepreneurs' current vision of success is directed towards a combination of economic, social, and personal achievements [87]. The existence of two generational profiles of entrepreneurs with different conceptions of success was identified, and it was revealed that entrepreneurs born before the middle of the 20th century stuck to a traditional vision of what success is: earning money, growing the business by making it more efficient and scalable, and surviving [88]. Entrepreneurs born in later decades incorporate new dimensions into their concept of success. Specifically, they understand success mainly as finding balance in their personal lives, contributing to society, and pursuing their passions.

\section{Methodology}

Our aim for this study was to understand the factors that influence the success of technology startups. To do this, we implemented a two-step methodology. First, we determined how to measure the success of technology startups and the variables with an influence on the success of technology startups (according to the literature review) using interviews with 50 entrepreneurs and 15 venture capital investors.

Then, to identify the factors that influence the indicators of success identified in the first step, we designed a questionnaire to be sent out to startups. The questions were structured according to the profile of each entrepreneur, focusing specifically on their training and professional experience; the type of technology startup; and the location, market, and financing of the startup. We carried out a pretest of the questionnaire with 60 technology startups. This made it possible to improve the wording of our questionnaire and remove questions that have caused entrepreneurs to reject answering the survey, thereby lowering our response rate.

At the time of carrying out this research, there was no official or unique registry of existing technology startups. For this reason, we started our research by creating a database of startups in one country: Spain. We used a number of different sources to compile this list, including internet searches; listings of the companies that were part of the most relevant incubators and accelerators; the social media accounts (mainly Twitter) followed by the primary investors in startups nationwide; analysis of the startups in which these aforementioned investors had invested; different publications related to startups; national awards for entrepreneurs; and specific web portals aimed at startups.

With all of these resources, it was possible to build a database of 2600 startups, to which we emailed our questionnaire. After disregarding some of the answers we received for a variety of reasons (e.g., incomplete questionnaires), we obtained 340 valid responses, for a response rate of $13.08 \%$.

Table 4 shows the variables used in our analysis and explains the relationship between the variables chosen in the model and the factors found in the literature review. 
Table 4. Operationalization of variables.

\begin{tabular}{|c|c|c|c|}
\hline Variable & Definition & Factors & Group of Factors \\
\hline Revenue success & $\begin{array}{l}\text { Binary: } 1 \text { if the annual revenue is } \\
\text { greater than EUR 100,000; } 0 \text { otherwise }\end{array}$ & $\begin{array}{c}\text { Development of a financial strategy: } \\
\text { initial investment and opening to } \\
\text { equity capital }\end{array}$ & Company \\
\hline Financing success & $\begin{array}{l}\text { Binary: } 1 \text { if the company has received } \\
\text { financing; } 0 \text { otherwise }\end{array}$ & $\begin{array}{l}\text { Financial constraints } \\
\text { (e.g., sources of financing) }\end{array}$ & Environment \\
\hline Age & $\begin{array}{l}\text { Average age of the promoting partners } \\
(1=\text { under } 25 ; 2=25 \text { to } 35 ; 3=36 \text { to } 45 \\
44=\text { over } 45)\end{array}$ & Age & Entrepreneur \\
\hline Dedication & $\begin{array}{l}\text { Average dedication to the startup by } \\
\text { the promoting partners }(0=\text { less than } \\
\text { half a working day; } 1=\text { half a working } \\
\text { day; } 2=\text { full-time })\end{array}$ & $\begin{array}{l}\text { Definition and development of a } \\
\text { business strategy for the startup }\end{array}$ & Company \\
\hline Commercial ability & $\begin{array}{l}\text { Average level of skill and experience of } \\
\text { the promoting partners in the } \\
\text { marketing and commercial area } \\
(0=\text { None; } 1=\text { Basic; } 2=\text { Intermediate; } \\
3=\text { Advanced; } 4=\text { Expert })\end{array}$ & $\begin{array}{l}\text { Skills, abilities, and previous } \\
\text { managerial and } \\
\text { commercial experience }\end{array}$ & Entrepreneur \\
\hline Incubator/Accelerator & $\begin{array}{l}\text { Binary: } 1 \text { if the company is currently or } \\
\text { has previously been in an } \\
\text { incubator/accelerator; } 0 \text { otherwise }\end{array}$ & $\begin{array}{l}\text { Support received from } \\
\text { public administrations }\end{array}$ & Environment \\
\hline Startup age & Age of the company in years & Startup age & Company \\
\hline Workers & $\begin{array}{l}\text { Number of workers in the startup, } \\
\text { including the promoting partners }\end{array}$ & Size of the startup & Company \\
\hline Nonpromoting partners & $\begin{array}{l}\text { Number of nonpromoting partners } \\
\text { in startup }\end{array}$ & $\begin{array}{c}\text { Development of a financial strategy: } \\
\text { initial investment and opening to } \\
\text { equity capital }\end{array}$ & Company \\
\hline Technological training & $\begin{array}{l}\text { Percentage of partners who have } \\
\text { graduate or postgraduate training or } \\
\text { an advanced degree in the field } \\
\text { of technology }\end{array}$ & Training & Entrepreneur \\
\hline Startups created & $\begin{array}{l}\text { Total number of startups created by the } \\
\text { promoting partners prior to the } \\
\text { creation of the current startup }\end{array}$ & $\begin{array}{l}\text { Previous experience as a founder of } \\
\text { other startups }\end{array}$ & Entrepreneur \\
\hline Breakeven & $\begin{array}{c}\text { Binary: } 1 \text { if the company has reached } \\
\text { breakeven point; } 0 \text { otherwise }\end{array}$ & Good financial health & Company \\
\hline Geographical region & Control variable & $\begin{array}{l}\text { Location, effects of cities } \\
\text { and infrastructure }\end{array}$ & Environment \\
\hline
\end{tabular}

Table 5 shows the variables used in our analysis of these questionnaires and their main descriptive statistics. We included two dependent variables that effectively measure success (which will be described in more detail in the Results section): having achieved an annual revenue of more than EUR 100,000 and having obtained financing.

Based on this sample, $25.5 \%$ of the companies had reached the level of revenue required to be considered successful and $40.2 \%$ had received financing.

With respect to the independent variables, the profile of the participants in our sample is of promoting partners that are less than 35 years old, with a certain commercial ability, usually without a degree in the technology field, and with previous experience in creating startups. 
Regarding the characteristics of the participating startups, they are, on average, 4 years old with 5.6 employees (std. $=1.9) ; 31.4 \%$ are currently part of an incubator/accelerator or have been in the past; and they have an average of 1.5 nonpromoting investor partners $($ std. $=1.65)$. Finally, $19.8 \%$ of these startups had reached the breakeven point.

Table 5. Descriptive statistics.

\begin{tabular}{ccccc}
\hline Variable & Mean & Std. Dev & Min. & Max. \\
\hline Revenue success & 0.255 & - & 0 & 1 \\
Financing success & 0.402 & - & 0 & 1 \\
Age & 1.650 & 0.920 & 1 & 4 \\
Dedication & 0.841 & 0.290 & 0 & 2 \\
Commercial ability & 2.493 & 1.012 & 0 & 4 \\
Incubator/Accelerator & 0.314 & - & 0 & 1 \\
Startup age & 3.838 & 1.873 & 1 & 9 \\
Workers & 5.577 & 1.914 & 0 & 150 \\
Nonpromoting partners & 1.470 & 1.645 & 0 & 4 \\
Technological training & 0.230 & 0.203 & 0 & 0.5 \\
Startups created & 1.410 & 1.440 & 0 & 4 \\
Breakeven & 0.198 & - & 0 & 1 \\
\hline
\end{tabular}

\section{Econometric Analysis and Empirical Strategy}

From the perspective of empirical strategy, we analyzed three groups of factors that impact the success of a startup: the profile of the entrepreneur, the strategy and characteristics of the company, and the influence of the environment. Using these indicators, we identified a series of variables associated with each of the aforementioned groups. We developed an empirical strategy to analyze the success of startups in two different ways using multivariate estimates: first, for achieving significant revenue; second, for obtaining financing. We analyzed the correlation matrix between the variables used. All the correlations between the variables are low (below 0.49). Additionally, we performed the VIF test, which reflected that there are no multicollinearity issues since all the VIF values are lower than 2 and, thus, far from the strictest threshold of 5 (mean VIF $=1.16$ ).

For both endogenous variables, we considered the geographical region as a control variable. The inclusion of dummies to the regional level allowed us to capture factors that are related to spatial factors, such as the existence of synergies due to location, access to basic infrastructures, and access to more dynamic labor markets, among others. Given the characteristics of the sample, we consider that these factors, if they exist, arise at the level of the existing autonomous communities (regions) in Spain. We based this interpretation on the fact that the management of economic promotion is the responsibility of each autonomous community.

However, to prevent the loss of explanatory capacity in the estimations due to the loss of degrees of freedom, we did not separately analyze the 17 autonomous communities that exist in Spain. Instead, we analyzed possible differences between four groups: Madrid, Catalonia, the Canary Islands, and the other 14 autonomous communities. These groups were created primarily based on the number of startups that answered from each territory. More specifically, we included Madrid and Catalonia separately because of their size, and the presence of the two main centers of entrepreneurship in the country: Madrid and Barcelona, respectively. In the case of the Canary Islands, the differentiation lies in it being a fragmented territory with more than one main economic pole and in its distance from the Spanish Mainland. The rest of the autonomous communities were considered in one group.

We also added the cluster option in the estimate, relative to the location of the startup. The inclusion of these cluster-type standard errors at the regional level allowed us to capture the potential existence of unknown correlations between standard errors in the observations of each region in Spain, and thus, to improve the precision of the estimators. 


\section{Results}

From the responses obtained in the first step of our study, we were able to conclude that success can be measured in two ways: the startup manages to achieve significant revenue and the startup receives financing. Thus, we used these two factors to measure startup success (see Table 4). Regarding revenue, more than $75 \%$ of the entrepreneurs and investors interviewed in the first step of our methodology considered that the figure of EUR 100,000 could be used as a relevant threshold. Therefore, this was the cut-off that we used.

We defined the first dependent variable based on revenue. This variable was coded as 1 for startups that had a revenue greater than EUR 100,000. Based on these requirements and given the small number of startups in our sample that met these criteria (approximately one-quarter), we established our estimate following a complementary log-log model, which reduces the bias derived from asymmetry in the distribution. The results of this analysis, presented in Table 6, were achieved using the following functional form:

$$
\begin{aligned}
& \text { Revenue success }_{i}=\beta 0+\beta 1 \text { Age }_{i}+\beta 2 \text { Dedication }_{i}+\beta 3 \text { Commercial ability }_{i}+ \\
& \beta 4 \text { Incubator/Accelerator }_{i}+\beta 5 \text { Startup age }_{i}+\beta 6 \text { Workers }_{i}+\beta 7 \text { Nonpromoting partners }_{i}+ \\
& \beta 8 \text { Technological training }{ }_{i}+\beta 9 \text { Startups sreated }_{i}+\beta 10 \text { Breakeven }_{i}+ \\
& \beta 11 \text { Catalonia }_{i}+\beta 12 \text { DMadrid }_{i}+\beta 13 D \text { Restof } A C_{i}+U_{i} .
\end{aligned}
$$

Table 6. Estimate of achieving significant revenue.

\begin{tabular}{lcc}
\hline \multicolumn{1}{c}{ Variables } & $\begin{array}{c}\text { Model 1a } \\
\text { (Only Control Variable) }\end{array}$ & $\begin{array}{c}\text { Model 1b (including } \\
\text { Explanatory Factors) }\end{array}$ \\
\hline Geographical region & Baseline & Baseline \\
Canary Islands & $1.797(0.000)^{* * *}$ & $0.830(0.495)^{*}$ \\
Catalonia & $1.634(0.000)^{* * *}$ & $1.036(0.522)^{* *}$ \\
Madrid & $1.338(0.000)^{* * *}$ & $1.360(0.456)^{* * *}$ \\
Rest of Autonomous Communities & & $-0.756(0.269)^{* * *}$ \\
Explanatory factors & - & $1.818(0.581)^{* * *}$ \\
Age & - & $0.701(0.246)^{* * *}$ \\
Dedication & - & $-0.771(0.298)^{* * *}$ \\
Commercial ability & - & $0.486(0.109)^{* * *}$ \\
Incubator $/$ accelerator & - & $0.041(0.148)^{* * *}$ \\
Startup age & - & $0.296(0.097)^{* * *}$ \\
Workers & - & $2.05(0.764)^{* *}$ \\
Nonpromoting partners & - & $0.034(0.066)$ \\
Technological training & - & $1.883(0.495)^{* * *}$ \\
Startups created & - & 255 \\
Breakeven & 292 & \\
\hline Number of observations & & \\
\hline Notes: ${ }^{* * *} 1 \%, * * 5, * 10 \%$ significance. Standard errors are shown in brackets. & \\
\end{tabular}

Since the geographical region is a control variable, as explained in the previous section, two models were estimated regarding success based on revenue. The first model (Model 1a in Table 6) only included the control variable, while the second one (Model 1b) included the control variable and the explanatory variables.

Model 1a of Table 6 shows that geographical region has a significant effect on the possibility of obtaining revenue. This effect is maintained in Model $1 \mathrm{~b}$. There is a positive relationship among all the exogenous variables and the endogenous variable, except for two cases: the company is or has been in an incubator and/or an accelerator, and the age of the startup. Both of these cases present a negative relationship. The variables with the greatest influence are the partners' technological training, the partners' dedication, and whether the company has reached the breakeven point. All relationships are significant except for the number of startups created previously. 
As for the factors that influence the probability that a company will obtain financing, the estimation follows a logistic regression that allows us to obtain the probability of each possible event of the binary dependent variable, given that the proportions of both events (obtaining financing and not obtaining financing) have a similar weight in the sample. The results of the model, which are presented in Table 7, were obtained using the following functional form:

Financing success $_{i}=\beta 0+\beta 1$ Age $_{i}+\beta 2$ Dedication $_{i}+\beta 3$ Commercial ability $_{i}+$ $\beta 4$ Incubator/Accelerator $_{i}+\beta 5$ Startup age $_{i}+\beta 6$ Workers $_{i}+$

$\beta 7$ Nonpromoting partners $_{i}+\beta 8$ Technological training $_{i}+\beta 9{\text { Startups } \text { created }_{i}+}+$ $\beta 10$ Breakeven $_{i}+\beta 11$ Datalonia $_{i}+\beta 12$ DMadrid $_{i}+\beta 13$ DRestofAC $_{i}+U_{i}$.

Table 7. Estimate of obtaining financing.

\begin{tabular}{|c|c|c|c|c|}
\hline \multirow{2}{*}{ Variables } & \multicolumn{2}{|c|}{ Model 2a (Only Control Variable) } & \multicolumn{2}{|c|}{ Model 2b (including Explanatory Factors) } \\
\hline & Coef. and Std. Err & Odds Ratio & Marginal Effects & Coef. and Std. Err \\
\hline \multicolumn{5}{|l|}{ Geographical region } \\
\hline Canary Islands & Baseline & Baseline & Baseline & Baseline \\
\hline Catalonia & $0.539(0.000)^{* * *}$ & $1.168(0.730)$ & $0.0261(0.104)$ & $0.156(0.176)$ \\
\hline Madrid & $0.236(0.000)^{* * *}$ & $1.421(0.827)$ & $0.589(0.097)$ & $0.351(0.241)$ \\
\hline Rest of Autonomous Communities & $0.120(0.000)$ & $1.367(0.744)$ & $0.052(0.091)$ & $0.312(0.281)$ \\
\hline \multicolumn{5}{|l|}{ Explanatory factors } \\
\hline Age & - & $0.999(0.166)$ & $-0.001(0.027)$ & $-0.009(0.12)$ \\
\hline Dedication & - & $3.456(2.087)^{* * *}$ & $0.208(0.098)^{* * *}$ & $1.240(0.324)^{* * *}$ \\
\hline Commercial ability & - & $0.938(0.169)$ & $-0.100(0.030)$ & $-0.063(0.289)$ \\
\hline Incubator/accelerator & - & $2.315(0.840)^{* * *}$ & $0.140(0.05) *$ & $0.839(0.470) *$ \\
\hline Startup age & - & $1.437(0.144)^{* * *}$ & $0.060(0.015)^{* * *}$ & $0.363(0.115) * * *$ \\
\hline Workers & & $0.998(0.018)$ & $-0.0002(0.003)$ & $-0.001(0.007)$ \\
\hline Nonpromoting partners & & $1.821(0.193)^{* * *}$ & $0.100(0.013)^{* * *}$ & $0.599(0.065)^{* * *}$ \\
\hline Technological training & - & $1.234(0.996)$ & $0.035(0.131)$ & $0.210(1.160)$ \\
\hline Startups created & - & $1.291(0.153)^{* * *}$ & $0.042(0.019)^{* * *}$ & $0.255(0.095)^{* * *}$ \\
\hline Breakeven & - & $0.192(0.092)^{* * *}$ & $-0.276(0.074)^{* * *}$ & $-1.649(0.458) * * *$ \\
\hline Pseudo $\mathrm{R}^{2}$ & \multicolumn{2}{|c|}{0.004} & \multicolumn{2}{|c|}{0.263} \\
\hline Number of observations & \multicolumn{2}{|c|}{305} & \multicolumn{2}{|c|}{256} \\
\hline
\end{tabular}

Notes: ${ }^{* * *} 1 \%,{ }^{*} 10 \%$ significance. Standard errors are shown in brackets.

As in the previous case, we estimated two models, which are shown in Table 7. Model 2a only includes the control variable, while Model $2 \mathrm{~b}$ includes the control variable and the explanatory factors.

As we can see in Model 2a (Table 7), the geographical region is significant, but with a very low explanatory capacity $(0.4 \%)$. In fact, when we join the control variable with the rest of the explanatory variables, it stops being significant. Therefore, our results show that the geographic location of a startup does not influence its ability to obtain financing. Model $2 \mathrm{~b}$ has global significance and the independent variables show an explanatory capacity of $26.3 \%$ of the variability of the dependent variable. This model highlights the fact that being part of, or having been part of, an accelerator and/or incubator favors a startup's ability to secure financing.

\section{Discussion}

In the case of measuring success from the point of view of achieving significant revenue, the estimated model suggests that location is significant. Specifically, the proximity of the startup to the largest centers of entrepreneurship in Spain (Madrid and Barcelona) is positively associated with achieving significant revenue. It is important to highlight that this research analyzed technology-based companies, so we expected to find that physical location would have less of an importance for success, but in fact, access to financing is the variable unaffected by a company's location. 
The first model indicates that the variables that impact and influence a greater probability of achieving significant revenue are promoting partners' dedication to the startup, their level of skill and experience in the commercial field, and the age of the startup. Conversely, currently being or having previously been in an incubator and/or an accelerator negatively affects the probability of securing a significant amount of revenue.

Finally, the results show that there is a greater probability of obtaining financing if the startup has nonpromoting partners (i.e., investors), if the entrepreneurs have previous experience in creating startups, and if the startup is currently or has previously been in an incubator and/or an accelerator. Conversely, there is a lower probability of obtaining financing if the company has reached the breakeven point.

Table 8 presents a summary of the variables that influence each way of measuring the success of startups.

Table 8. Variables that influence the success of startups.

\begin{tabular}{cccc}
\hline Predictors & Type of Variable & $\begin{array}{c}\text { To Achieve } \\
\text { Significant Revenue }\end{array}$ & $\begin{array}{c}\text { To Obtain } \\
\text { Financing }\end{array}$ \\
\hline Age & Independent & $* * *(-)$ & n.s. \\
Dedication & Independent & $* * *$ & n.s. \\
Commercial ability & Independent & $* * *$ & $* *$ \\
Incubator/accelerator & Independent & $* *(-)$ & $* * *$ \\
Startup age & Independent & $* * *$ & n.s. \\
Workers & Independent & $* * *$ & n.s. \\
Nonpromoting partners & Independent & $* * *$ & $* * *$ \\
Technological training & Independent & n.s. & $* * *(-)$ \\
Startups created & Independent & Independent & n.s. \\
Breakeven & Control & $* * *$ & . \\
Geographical region & Notes: ${ }^{* * *} 1 \%, * * 5 \%$ significance; $(-)$ significant variable but with negative effect; n.s., nonsignificant variable.
\end{tabular}

As Table 8 shows, the factors that significantly and positively influence the probability of achieving significant revenue are the dedication of the promoting partners, their commercial ability, the age of the company, the number of workers, the existence of nonpromoting partners in the company, the technological training of the promoting partners, and the startup having reached the breakeven point. In contrast, the age of the promoting partners and being or having been in an incubator and/or an accelerator have a negative influence.

From the perspective of obtaining financing, the dedication of the promoting partners, being or having been in an incubator and/or an accelerator, the age of the company, having investment partners (that is, nonpromoting partners) in the startup, and having previously created other startups all have a positive influence. On the other hand, having reached the breakeven point has a negative influence on the probability of obtaining financing, likely because the founders will not require this financing or will not be overly aggressive in searching for it.

With these results, we can propose a series of recommendations for entrepreneurs and public policy managers. Entrepreneurs should try to incorporate nonpromoting partners from the early stages because doing so has a positive impact both on the possibility of achieving significant revenue and on access to financing. On the other hand, startup managers located in territories far from the entrepreneurial poles should be aware that they will face additional difficulties in the process of achieving significant revenue capacity. Consequently, even if they initially create their startup in another place, they must understand that to invoice significantly, they will probably have to move to or open a branch in one of the aforementioned poles of entrepreneurship in their geographic area.

Public policy managers engaged in entrepreneurship policy making and/or promoting technological entrepreneurship should be aware of the importance of location to a startup's probability of significant invoicing. In the same vein, and given the results of our research, it is clear that the dedication of the entrepreneurs to the startup is key for its success. 
We believe that policy makers should take this issue into consideration by prioritizing startups in which the entrepreneurs are fully dedicated to the project. Last, we also recommend that policy makers promoting technological entrepreneurship should provide training in technological areas for entrepreneurs who may have a certain absence of knowledge in this area. The negative effect of being or having been in an incubator and/or an accelerator with respect to the probability of invoicing significantly indicates that the support of incubators and accelerators is more important in a startup's beginning stages because it solves entrepreneurs' first basic problems. In this sense, our results indicate that while incubators and accelerators facilitate startups in obtaining their first financing, they can also compromise the future success of the startup.

\section{Conclusions}

From an academic point of view, this research contributes to the field of technological entrepreneurship by developing an integrated model of the factors that influence the success of such startups, a task that has been recognized in the literature as difficult. This research also contributes by presenting two possible ways of measuring the success of a technological startup: obtaining financing and achieving a significant level of revenue.

From a practical perspective, this research provides a series of clues for technology startup entrepreneurs. The conclusions of this research are helpful for understanding the key factors that have an impact on the potential success of startups. In the same vein, the results of our research are equally interesting to policy makers who want to support and encourage startups to be successful. In this sense, the conclusions of the present study can be grouped into two main categories. First, following a review of the literature and direct consultation with 50 entrepreneurs and 15 venture capital investors, we were able to identify two ways of measuring the success of a startup - an issue that, until now, had not been resolved in the literature. According to our research, a startup can be considered successful when it generates significant revenue (more than EUR 100,000 a year according to the participants in our research) and when it obtains financing.

Second, based on a sample of 340 startups located in Spain, we analyzed the factors that have the greatest impact on the success of startups. When analyzing these factors, we used three aspects mentioned in the literature that may have an impact on startup success: the profile of the entrepreneur, the strategy and characteristics of the company, and the influence of the environment. With respect to the dependent variable, we used the two ways of measuring success identified in the first phase of the present study along with a multivariate model based on independent econometric estimates for each of the two.

Our analyses allowed us to conclude that, on the one hand, the location of the startup is essential in relation to the startup's probability of achieving significant revenue. On the other hand, the location was not found to be important in relation to the probability of obtaining financing.

There are multiple other indicators that help to positively predict the possible success of a startup. To achieve significant revenue, the promoting partners' dedication, their commercial abilities, the age of the startup, the number of workers in the startup, the presence of nonpromoting partners, the startup's ability to reach the breakeven point, and the promoting partners' technological background all positively impact a startup's potential for success. On the contrary, the age of the promoting partners and whether the company is or has been located in an incubator and/or an accelerator have negative influences on a startup's probability of success.

In the case of obtaining financing, the dedication of the promoting partners, being or having been in an incubator and/or an accelerator, the age of the startup, having nonpromoting partners, and having created a startup previously all positively affect the probability of obtaining financing. In contrast, having reached the breakeven point adversely affects the probability of obtaining financing. 


\section{Limitations and Future Lines of Research}

This research presents a series of limitations that, in turn, allow us to suggest future lines of research. First, this work focused on a sample of startups located in one countrySpain. Although we understand that we had a broad and representative database of the Spanish reality, the size of our database made it impossible to carry out certain analyses in specific groups (e.g., among startups located in incubators and accelerators) that are necessary for examining some phenomena in greater depth.

For this reason, in future research, it would be valuable to expand this study into other geographical contexts to verify the degree of generalization possible from the results we have obtained. Additionally, the present study leaves open possibilities for future research regarding other factors that may influence the success of startups. There are other variables apart from those used in this research (e.g., the number of countries in which the startup operates) that could be tested in the future. Furthermore, the definition of success we have used is not exclusive; we have focused on identifying measures of success of technology startups, but the ones proposed here are not the only ones. In our study, we analyzed startups at a specific point in time, providing a static picture of the startup, but a longitudinal study would allow us to examine how technology startups that have been successful in their first growth phase (e.g., in the first 6 to 12 months) evolve.

Finally, given that there is no clear consensus in the literature on what the success of startups is, we conducted interviews with entrepreneurs and venture capital investors to identify possible definitions of startup success. However, we believe that there may be other options to operationalize startup success that could be explored in future research.

Author Contributions: Conceptualization, C.D.-S. and J.B.-G.; methodology, C.D.-S. and J.B.-G.; software, C.D.-S. and J.B.-G.; validation, C.D.-S. and J.B.-G.; formal analysis, C.D.-S. and J.B.-G.; investigation, C.D.-S. and J.B.-G.; resources, C.D.-S. and J.B.-G.; data curation, C.D.-S. and J.B.-G.; writing-original draft preparation, C.D.-S.; writing—review and editing, C.D.-S. and J.B.-G.; visualization, J.B.-G.; supervision, J.B.-G.; project administration, C.D.-S. All authors have read and agreed to the published version of the manuscript.

Funding: This research received no external funding.

Institutional Review Board Statement: Not applicable.

Informed Consent Statement: Not applicable.

Data Availability Statement: The data presented in this study are available on request from the corresponding author. The data are not publicly available due to privacy concerns.

Conflicts of Interest: The authors declare no conflict of interest.

\section{References}

1. Kim, D.J. Is there a startup wage premium? Evidence from MIT graduates. Res. Policy 2018, 47, 637-649. [CrossRef]

2. Sulayman, M.; Mendes, E.; Urquhart, C.; Riaz, M.; Tempero, E. Towards a theoretical framework of SPI success factors for small and medium web companies. Inf. Softw. Technol. 2014, 56, 807-820. [CrossRef]

3. Wheadon, M.; Duval-Couetil, N. Token entrepreneurs: A review of gender, capital, and context in technology entrepreneurship. Entrep. Reg. Dev. 2019, 31, 308-336. [CrossRef]

4. Adler, P.; Florida, R.; King, K.; Mellander, C. The city and high-tech startups: The spatial organization of Schumpeterian Entrepreneurship. Cities 2018, 87, 121-130. [CrossRef]

5. Blank, S. Why the lean start-up changes everything. Harv. Bus. Rev. 2013, 91, 63-72.

6. Voicu-Dorobantu, R.; Jinaru, A.; Caragea, A. The Collaborative Poles Network And The Development Of An Efficient Entrepreneurial Ecosystem. Sea-Pract. Appl. Sci. 2014, 5, 681-688.

7. Cavallo, A.; Ghezzi, A.; Balocco, R. Entrepreneurial ecosystem research: Present debates and future directions. Int. Entrep. Manag. J. 2019, 15, 1291-1321. [CrossRef]

8. Grimpe, C.; Murmann, M.; Sofka, W. Organizational design choices of high-tech startups: How middle management drives innovation performance. Strateg. Entrep. J. 2019, 13, 359-378. [CrossRef]

9. OECD. OECD Science, Technology and Industry Scoreboard 2017, Innovation for Growth; OECD Publishing: Paris, France, 2017. [CrossRef] 
10. Saura, J.R.; Palos-Sánchez, P. Detecting Indicators for Startup Business Success: Sentiment Analysis Using Text Data Mining. Sustainability 2019, 11, 917. [CrossRef]

11. Mercandetti, F.; Larbig, C.; Tuozzo, V.; Steiner, T. Innovation by Collaboration Between Startups and SMEs in Switzerland. Technol. Innov. Manag. Rev. 2017, 7, 23-31. [CrossRef]

12. Espinoza, C.; Mardones, C.; Sáez, K.; Catalán, P. Entrepreneurship and regional dynamics: The case of Chile. Entrep. Reg. Dev. 2019, 31, 755-767. [CrossRef]

13. Okrah, J.; Nepp, A.; Agbozo, E. Exploring the factors of startup success and growth. Bus. Manag. Rev. 2018, 9, $229-237$.

14. Van Winden, W.; Carvalho, L. Intermediation in public procurement of innovation: How Amsterdam's startup-in-residence programme connects startups to urban challenges. Res. Policy 2019, 48. [CrossRef]

15. Del Bosco, B.; Mazzucchelli, A.; Chierici, R.; Di Gregorio, A. Innovative startup creation: The effect of local factors and demographic characteristics of entrepreneurs. Int. Entrep. Manag. J. 2019. [CrossRef]

16. Cohen, S.; Fehder, D.C.; Hochberg, Y.V.; Murray, F. The design of startup accelerators. Res. Policy 2019, 48, 1781-1797. [CrossRef]

17. Chan, C.S.R.; Patel, P.C.; Phan, P.H. Do differences among accelerators explain differences in the performance of member ventures? Evidence from 117 accelerators in 22 countries. Strateg. Entrep. J. 2020, 14, 224-239. [CrossRef]

18. Busch, C.; Barkema, H. Planned Luck: How Incubators Can Facilitate Serendipity for Nascent Entrepreneurs Through Fostering Network Embeddedness. Entrep. Theory Pract. 2020. [CrossRef]

19. Islam, M.; Fremeth, A.; Marcus, A. Signaling by early stage startups: US government research grants and venture capital funding. J. Bus. Ventur. 2018, 33, 33-51. [CrossRef]

20. Santisteban, J.; Mauricio, D. Systematic Literature Review of Critical Success Factors of Information Technology Startups. Acad. Entrep. J. 2017, 23, 1-23.

21. Blenker, P. Towards a sociological and anthropological understanding of entrepreneurship and small business. Presented at the Rent VI Research on Entrepreneurship, Barcelona, Spain, 15 June 1992.

22. Kham, A.M. Entrepreneur Characteristics and the Prediction of New Venture Success. Omega 1986, 14, 365-372. [CrossRef]

23. McMillan, I.C.; Siegel, R.; Subba, P.N. Criteria Used by Venture Capitalist to Evaluate New Venture Proposals. J. Bus. Ventur. 1985, 1, 119-128. [CrossRef]

24. Sandberg, W.R.; Hofer, C.W. Improving New Venture Perfomance: The Role of Strategy, Industry Structure, and the Entrepreneur. J. Bus. Ventur. 1987, 2, 5-28. [CrossRef]

25. Stuart, R.W.; Abetti, P.A. Start-up Ventures: Towards the Predictions of Inicial Success. J. Bus. Ventur. 1987, 2, 215-230. [CrossRef]

26. Covin, J.G.; Slevin, D.P. Strategic management of small firms in hostile and benign environments. Strateg. Manag. J. 1989, 10, 75-87. [CrossRef]

27. Duchesneau, D.A.; Gartner, W.B. A profile of new venture success and failure in an emerging industry. J. Bus. Ventur. 1990, 5, 297-312. [CrossRef]

28. Feeser, H.R.; Willard, G.E. Founding strategy and performance: A comparison of high and low growth high tech firms. Strateg. Manag. J. 1990, 11, 87-98. [CrossRef]

29. Henderson, V.; Kuncoro, A.; Turner, M. Industrial development in cities. J. Political Econ. 1995, 103, 1067-1090. [CrossRef]

30. Johnson, P.S.; Cathcart, D.G. The Founders of New Manufacturing Firms: A note on the size of their Incubator' plants. J. Ind. Econ. 1979, 28, 219-224. [CrossRef]

31. Mintzberg, H.; McHugh, A. Strategic formation in an adhocracy. Adm. Sci. Q. 1985, 30, 160-197. [CrossRef]

32. Ripollés, M. El emprendedor y sus mitos. Dir. Y Organ. 1995, 15, 36-44.

33. Romanelli, E. Environments and strategies of organization start-up: Effects on early survival. Adm. Sci. Q. 1989, 34, 369-387. [CrossRef]

34. Sandberg, W.R.; Hofer, C.W. The Effects of Strategy and Industry Structure on New Venture Performance. Front. Entrep. Res. 1986, 15, 244-266.

35. Storey, D.J. Understanding the Small Business Sector 1994. Available online: https://papers.ssrn.com/sol3/papers.cfm?abstract_ id=1496214 (accessed on 19 November 2020).

36. Stuart, R.W.; Abetti, P.A. Impact of entrepreneurial and management experience on early performance. J. Bus. Ventur. 1990, 5, 151-162. [CrossRef]

37. Taylor, M. The survival of the fittest: An analysis of self-employment duration in Britain. Econ. J. 1999, 109, 140-155. [CrossRef]

38. Arkebauer, J.B. Ultrapreneuring: Taking a Venture from Start-Up to Harvest in Three Years or Less; McGraw-Hill, Inc.: New York, NY, USA, 1993.

39. Bhave, M.P. A process model of entrepreneurial venture creation. J. Bus. Ventur. 1994, 9, 223-242. [CrossRef]

40. Bosma, N.; Van Praag, M.; Thurik, R.; de Wit, G. The value of human and social capital investments for the business performance of startups. Small Bus. Econ. 2004, 23, 227-236. [CrossRef]

41. Bruno, A.V.; Leidecker, J.K.; Harder, J.W. Why firms fail. Bus. Horiz. 1987, 30, 50-58. [CrossRef]

42. Deakins, D.; Freel, M. Entrepreneurial learning and the growth process in SMEs. Learn. Organ. 1998, 5, 144-155. [CrossRef]

43. Gaglio, C.M.; Katz, J.A. The psychological basis of opportunity identification: Entrepreneurial alertness. Small Bus. Econ. 2001, 16, 95-111. [CrossRef]

44. Hamilton, B.H. Does entrepreneurship pay? An empirical analysis of the returns to self employment. J. Political Econ. 2000, 108, 604-631. [CrossRef] 
45. Kao, J.J. Entrepreneurship, Creativity and Organization; Prentice-Hall: Englewood Cliffs, NJ, USA, 1989.

46. Smallbone, D. Success and failure in new business start-ups. Int. Small Bus. J. 1990, 8, 34-35. [CrossRef]

47. Smallbone, D.; Leig, R.; North, D. The characteristics and strategies of high growth SMEs. Int. J. Entrep. Behav. Res. 1995, 1, 44-62. [CrossRef]

48. Timmons, J. New Venture Creation: Entrepreneurship for the 21st Century, 4th ed.; Irwin/McGraw Hill: Burr Ridge, IL, USA, 1994.

49. Vesper, K. New Venture Strategies, Revised ed.; Pearson: Washington, DC, USA, 1990.

50. Beckman, C.M.; Burton, M.D. Founding the future: Path dependence in the evolution of top management teams from founding to IPO. Organ. Sci. 2008, 19, 3-24. [CrossRef]

51. Dyke, L.; Fischer, E.; Reuber, A. An interindustry examination of the impact of experience on entrepreneurial performance. J. Small Bus. Manag. 1992, 30, 72-87.

52. Holmes, T.; Schmitz, J. A Theory of Entrepreneurship and Its Application to the Study of Business Transfers. J. Political Econ. 1990, 98, 265-294. [CrossRef]

53. Quadrini, V. The importance of entrepreneurship for wealth concentration and mobility. Rev. Income Wealth 1999, 45, 1-19. [CrossRef]

54. Bates, T. Self-employment entry across industry groups. J. Bus. Ventur. 1995, 10, 143-156. [CrossRef]

55. Delmar, F.; Davidsson, P. Where do they come from? Prevalence and characteristics of nascent entrepreneurs. Entrep. Reg. Dev. 2000, 12, 1-23. [CrossRef]

56. Honig, B. Human capital and structural upheaval. A study of manufacturing firms in the West Bank. J. Bus. Ventur. 2001, 16, 575-594. [CrossRef]

57. Reynolds, P.D. Who start new firms? Preliminary explorations of firms-ingestation. Small Bus. Econ. 1997, 9, 449-462. [CrossRef]

58. Ritsila, J.; Tervo, H. Effects of unemployment on new firm formation: Microlevel panel data evidence from Finland. Small Bus. Econ. 2002, 19, 31-40. [CrossRef]

59. van der Sluis, J.; van Praag, M.; Vijverberg, W. Entrepreneurship selection and performance: A meta-analysis of the role of education in developing economies. World Bank Econ. Rev. 2004, 19, 225-261. [CrossRef]

60. Carter, N.M.; Stearns, T.M.; Reynolds, P.D.; Miller, B.A. New Venture Strategies: Theory Development with an Empirical Base. Strateg. Manag. J. 1994, 15, 21-41. [CrossRef]

61. McDougall, P.P.; Covin, J.G.; Robinson, R.B.; Herron, L. The Effects of Industry Growth and Strategic Breadth on New Venture Performance and Strategy Content. Strateg. Manag. J. 1994, 15, 537-554. [CrossRef]

62. McDougall, P.P.; Robinson, R.B. New Venture Strategies: An Empirical Identification of Eight "Archetypes" of Competitive Strategies for Entry. Strateg. Manag. J. 1990, 11, 447-467. [CrossRef]

63. Romanelli, E. New Venture Strategies in the Minicomputer Industry. Calif. Manag. Rev. 1987, 30, 160-175. [CrossRef]

64. Geroski, P.A. What do we know about entry? Int. J. Ind. Organ. 1995, 13, 421-440. [CrossRef]

65. Audretsch, D. Start-Up Size and Establishment Exit. 1990. Available online: https://bibliothek.wzb.eu/pdf/1990/iv90-8.pdf (accessed on 19 November 2020).

66. Cooper, A.C. The entrepreneurship-small business interface. In Encyclopedia of Entrepreneurship; Kent, C.A., Sexton, D.L., Vesper, K.H., Eds.; Prentice-Hall: Englewood Cliffs, NJ, USA, 1982; pp. 193-205.

67. Keasy, K.; Watson, R. The state of the art of small business failure prediction: Achievements and prognosis. Int. Small Bus. J. 1991, 4, 11-29. [CrossRef]

68. Mata, J.; Portugal, P.; Guimaraes, Y. The survival of new plants: Start-up conditions and post-entry evolution. Int. J. Ind. Organ. 1995, 13, 459-481. [CrossRef]

69. Storey, D.J. The problems facing new firms. J. Manag. Stud. 1985, 22, 327-345. [CrossRef]

70. Sutton, J. Gibrat's legacy. J. Econ. Lit. 1997, XXXV, 40-59.

71. Cooper, A.C.; Gimeno-Gascon, F.J.; Woo, C.Y. A resource based prediction of new venture survival and growth. Acad. Manag. Proc. 1991, 1, 68-72. [CrossRef]

72. Wagner, J. The post-entry performance of new small firms in German manufacturing industries. J. Ind. Econ. 1994, 2, 141-154 [CrossRef]

73. Eisenhardt, K.M.; Schoonhoven, C.B. Organizational growth: Linking founding team, strategy, environment, and growth among US semiconductor Ventures, 1978-1988. Adm. Sci. Q. 1990, 35, 504-529. [CrossRef]

74. Maidique, M.A.; Patch, P. Corporate strategy and technological policy. Read. Manag. Innov. 1982, $25,273-285$.

75. Berryman, J. Small business failure and bankruptcy: A survey of the literature. Eur. Small Bus. J. 1983, 1, 47-59. [CrossRef]

76. Stearns, T.M.; Carter, N.M.; Reynolds, P.D. Strategy-Environment Interaction Affecting New Firm Growth. Presented at the Inaugural Global Conference on Entrepreneurship Research, London, UK, 18-20 February 1991.

77. Tsai, W.M.; MacMillan, I.C.; Low, M.B. Effects of Strategy and Environment on Corporate Venture Success in Industrial Markets. J. Bus. Ventur. 1991, 6, 9-28. [CrossRef]

78. Schutjens, V.A.; Wever, E. Determinants of new firm success. Pap. Reg. Sci. 2000, 79, 135-153. [CrossRef]

79. Boden, R.J.; Nucci, A.R. On the survival prospects of men's and women's new business ventures. J. Bus. Ventur. 2001, 15, 347-362. [CrossRef]

80. March-Chorda, I. Las claves del éxito en nuevas compañías innovadoras según los propios emprendedores. Rev. Dir. Organ. 1999, $21,167-176$. 
81. Nicholls-Nixon, C.; Cooper, A.; Woo, C. Strategic Experimentation Understanding Change and Performance in New Ventures. J. Bus. Ventur. 2000, 15, 493-521. [CrossRef]

82. Roberts, E.B. Entrepreneur in High Technology. Lesson from MIT and Beyond; Oxford University Press: New York, NY, USA, 1991.

83. Peña, I. Business incubation centers and new firm growth in the Basque Country. Small Bus. Econ. 2004, 22, 223-236. [CrossRef]

84. Hiemstra, A.M.F.; van der Kooy, G.; Frese, M. Entrepreneurship in the Street Food Sector of Vietnam Assessment of Psychological Success and Failure Factors. J. Small Bus. Manag. 2006, 44, 474-481. [CrossRef]

85. McCormack, J. How Much you Worthm John? About Unit. Bayl. Bus. Rev. 2003, 21, 22-29.

86. Restrepo, L.F.; Rivera, H.A. Análisis estructural de sectores estratégicos: Segunda edición corregida y mejorada; Centro Editorial Universidad del Rosario: Bogota, Colombia, 2008.

87. MIT Technology Review. Estas son las claves que han llevado al éxito a 110 emprendedores españoles. 2015. Available online: https://www.technologyreview.es/negocios/46783/estas-son-las-claves-que-han-llevado-al-exito-a/ (accessed on 19 November 2020).

88. Claire, L. Re-Storying the Entrepreneurial Ideal: Lifestyle Entrepreneurs as Hero? Tamara J. Crit. Organ. Inq. 2012, 10, 31-39. 